\title{
Implementasi Model Experiential Learning Pada Materi Kelipatan Persekutuan Terkecil dan Faktor Persekutuan Terbesar Kelas IV
}

\author{
Iesyah Rodliyah ${ }^{1 *}$, Sari Saraswati ${ }^{2}$, Nihayatus Sa'adah ${ }^{3}$ \\ 1,2,3 Universitas Hasyim Asy’ari, Kabupaten Jombang, Jawa Timur 61471, Indonesia \\ Pengiriman: 26 Agustus 2018; Diterima: 29 September 2018; Publikasi: 30 September 2018 \\ DOI: https://doi.org/10.31629/jg.v3i2.601
}

\begin{abstract}
Abstrak
Artikel ini adalah bagian dari penelitian besar pada pengembangan perangkat pembelajaran dengan strategi experiential learning berbasis game. Penelitian ini bertujuan untuk mendeskripsikan pelaksanaan strategi experiential learning pada materi KPK dan FPB di kelas IV. Model pembelajaran experiential learning ini dibuat dalam sebuah permainan yang dinamakan dengan Joyfull Clap Number untuk materi Kelipatan Persekutuan Terkecil (KPK) dan Magic Bag untuk materi Faktor Persekutuan Terbesar (FPB). Metode penelitian yang digunakan adalah kualitatif dengan model 4D yang kepanjangan dari define (pendefinisian), design (perancangan), develop (pengembangan) dan disseminate (penyebaran). Penelitian ini fokus pada deskripsi hasil disseminate. Teknik pengumpulan data diperoleh melalui lembar kerja siswa, observasi, rekaman video dan catatan lapangan. Teknis analisis data dilakukan dengan mengungkap data hasil rekaman video yang diperoleh selama penelitian selanjutnya dianalisa dan dikaitkan dengan teori yang digunakan. Subjek penelitian ini adalah siswa kelas IV SD di MI Makarimul Akhlaq dan MI Al Asy'ari. Hasil penelitian menunjukkan bahwa siswa dapat membentuk konsep dasar KPK dan FPB melalui strategi experiential learning selama proses pembelajaran.
\end{abstract}

Kata kunci: implementasi pembelajaran; experiential learning; KPK; FPB

\begin{abstract}
This article is part of a large development research with experiential learning using a game-based strategy. The aim of this research is to describe experiential learning on mathematics in LCM and GCD material for students of grade IV. Experiential learning was designed through a game which is called Joyfull Clap Number for Least Common Multiple (LCM) and Magic Bag for Greatest Common Divisor (GCD). The method was qualiative research using 4D model consisting of define, design, develop and disseminate. This research focused on the result of disseminate. Data were collected by spreading worksheet, conducting observation, video recording, and taking notes. Data were analized by expressing the video result during conducting experiential learning then analyzing and correlating the data with theory. Subject in this research were students in grade IV from MI Makarimul Akhlaq and MI Al Asy'ari. The result shows that students can construct the concept of LCM dan GCD.
\end{abstract}

Keywords: learning implementation; experiential learning; LCM; GCD 


\section{JURNAL GANTANG. September 2018; III(2): 143 - 151 \\ p-ISSN. 2503-0671 \\ e-ISSN. 2548-5547}

\section{Pendahuluan}

Matematika merupakan mata pelajaran yang penting diajarkan di sekolah. Hal ini terbukti bahwa matematika diperoleh siswa di setiap jenjang sekolah. Matematika yang diajarkan di tingkat SD/MI merupakan bagian sangat esensial karena dalam tahap ini merupakan proses penanaman konsep dasar dalam matematika.

Salah satu materi matematika yang penting diajarkan di SD/MI adalah Kelipatan Persekutuan Terkecil (KPK) dan Faktor Persekutuan Terbesar (FPB). Pada materi ini, siswa SD/MI sering merasa kesulitan untuk membedakan kapan harus menggunakan KPK dan FPB. Hal ini diperkuat oleh suatu fakta yang ditemukan peneliti berdasarkan observasi awal pada beberapa siswa SD/MI ketika membahas soal-soal cerita yang melibatkan materi FPB dan KPK. Para siswa banyak sekali melakukan kesalahan yang bisa disebabkan oleh beberapa hal, diantaranya kesalahan interpretasi, kesalahan konsep, kesalahan prinsip, dan kesalahan operasi. Pada saat observasi awal, peneliti menyajikan soal cerita sebagai berikut; "Rina berenang 10 hari sekali, Indri berenang 15 hari sekali, sedangkan Nia berenang 20 hari sekali. Ketigatiganya sama-sama berenang pertama kali pada tanggal 20 Pebruari 2018. Kapan ketiga-tiganya sama-sama berenang untuk yang kedua kalinya..."

Pada saat ditanya dan diminta menentukan jawaban, beberapa siswa banyak yang hanya diam karena tidak tahu bagaimana solusi penyelesaiannya, namun ada satu siswa yang menjawab dan berkata, "Saya bingung harus diapakan terlebih dahulu Bu, cari KPK atau FPB soal ini Bu?" Namun ada juga beberapa siswa yang memahami maksud soal tersebut namun terhenti pada hasil kesimpulannya. Ada juga yang mampu mengerjakan tetapi masih terdapat keraguan atau tidak percaya diri dengan jawabannya sambil mengatakan "Betul tidak Bu kalau dicari KPK dulu? Saya agak bingung." Hal ini menunjukkan bahwa masih banyak siswa belum memahami

konsep materi tersebut secara baik dan mendalam.

Fakta lain juga ditunjukkan pada hasil PISA 2015 (Programme International for Students Assesment) menunjukkan bahwa Indonesia menduduki peringkat 63 dari 70 negara. Sehingga peran guru perlu dimaksimalkan agar dapat membantu siswa memperoleh pengetahuan yang lebih bermakna.

Peran guru dalam kegiatan belajar mengajar (KBM) di sekolah tidak hanya mentransfer pengetahuan, namun siswa perlu turut aktif dalam KBM karena pengetahuan juga dapat dibentuk oleh proses sosial. Hal ini sejalan dengan Harfitt dan Chow (2018) yang mengatakan bahwa "teacher's expertise should not only reside in the knowledge domain typically established by university and schools". Selain itu, Bringle dan Hatcher (2003) memaparkan bahwa "the use of tarditional pedagogical method of lecture may add relatively little to students' knowledge since it ignores the role of experinece in knowledge formation", artinya bahwa penggunaan metode pembelajaran tradisional hanya membantu siswa memperoleh pengetahuan yang relatif sedikit (Manolis, Burns, Assudani, \& Chinta, 2013).

$$
\text { Henriksen dan Mehta }
$$

menjelaskan bahwa kreativitas menjadi salah satu kualitas berpikir yang paling penting dan diinginkan untuk mencapai kesuksesan di abad ke-21. Karena itu diperlukan suatu strategi yang dapat mendukung kreativitas siswa. Disamping itu, perlu adanya suatu pembelajaran yang bermakna untuk mendukung penguasaan konsep matematika yang baik.

Sharlanova (2004) mengatakan bahwa teori pembelajaran yang sangat populer dan sering digunakan dalam teori pendidikan salah satunya adalah experiential learning. Teori pembelajaran ini sangat mendukung dalam pembelajaran matematika. Pembelajaran experiential learning adalah pembelajaran yang dimulai dengan membenamkan peserta didik dalam sebuah pengalaman dan kemudian mendorong refkleksi tentang pengalaman untuk 
mengembangkan keterampilan baru, sikap baru, atau cara berfikir yang baru (Schwartz, 2013). Selain itu, Silberman (2014) menambahkan bahwa pembelajaran eksperiensial bisa didasarkan atas dasar pengalaman kerja/hidup yang nyata dan pengalaman terstruktur yang menyimulasikan atau mendekati pengalaman hidup yang sebenarnya.

Teori pembelajaran eksperiensial ini bisa mendorong siswa untuk aktif dan kreatif (Istighafroh, 2014). Akibatnya, pembelajaran matematika diharapkan menjadi tidak membosankan.

Silberman (2014) mengungkapkan bahwa game pemelajaran merupakan pendekatan utama dalam experiential learning. Pengalaman dini sebagai anak-anak menjadikan permainan sebagai salah satu jalan untuk menyalurkan pengetahuan kepada siswa.

Menurut Kolb dan Kolb (2008) bahwa experiential learning teridiri dari empat tahap yaitu:

1. Concreate experience, proses dimana belajar dimulai dari pengalaman konkret. Pada tahap ini menekankan pada dimana dan bagaimana peserta mendapat pengalaman selama proses pembelajaran.

2. Observation and reflections, dalam tahap ini pengalaman konkret yang diperoleh direfleksikan secara individu untuk dipahami dan dipikirkan.

3. Formations of abstract concept and generalizations, pada tahap ini hasil refleksi menjadi dasar pembentukan konsep dan pengalaman yang dialami dapat diterapkan dalam konteks baru.

4. Testing implementations, pada tahap implementasi ini, konsep yang diperoleh diterapkan dalam konteks dan situasi. Pembelajaran melalui pengalaman nyata kemudian direfleksikan dengan harapan dapat terbentuk suatu konsep.

Adapun tahapan pembelajaran experiential learning dapat dilihat pada gambar 1 berikut:

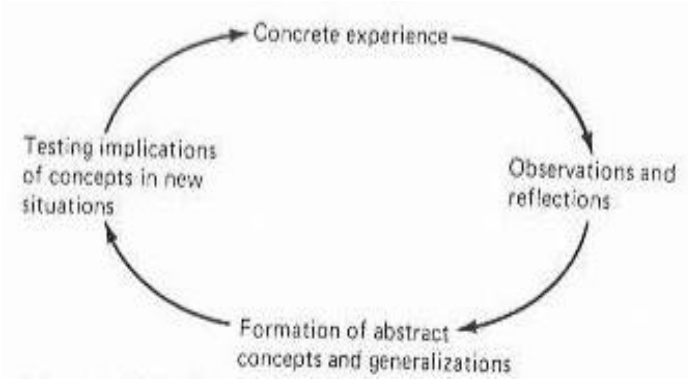

Gambar 1. Tahap experiential learning

Selain itu, Kolb (1984) dalam Istighafroh (2014) menjelaskan bahwa terdapat karakteristik experiential learning, yaitu:

1. Learning is the best conceived as a process, not in terms of outcomes. Belajar bukan saja suatu hasil tapi merupakan suatu proses.

2. Learning is a continuous process grounded in experience. Pembelajaran didasarkan pada pengalaman sehingga menjadi suatu proses yang berkesinambungan.

3. The process of learning requires the resolution of conflicts between dialectically opposed modes of adaptaion to the world. Dalam pembelajaran diperlukan suatu resolusi suatu permasalahan yang terjadi antara model yang berlawanan secara dialektis.

4. Learning is an holistic process of adaptation to the world. Belajar merupakan suatu proses yang holistik.

5. Learning involves transactions between the person and the environment. Dalam proses pembelajaran melibatkan peserta didik dengan lingkungan.

6. Learning is the process of creating knowledge. Pembelajaran merupakan suatu proses menciptakan suatu pengetahuan.

Penelitian yang relevan dengan penelitian ini adalah penelitian yang dilakukan oleh Prahmana (2010) dengan judul permainan "tepuk bergilir" yang berorientasi konstruktivisme dalam pembelajaran konsep KPK siswa kelas IV A. Pada penelitian ini, peneliti hanya fokus pada penanaman materi 


\section{JURNAL GANTANG. September 2018; III(2): 143 - 151 \\ p-ISSN. 2503-0671 \\ e-ISSN. 2548-5547}

KPK kepada siswa yang mana hasil penelitian menunjukkan hasil positif, karena siswa mampu memahami KPK dengan baik. Namun, untuk materi FPB belum ada pemaparan pada penelitian tersebut. Oleh karena itu, pada penelitian ini, peneliti juga menanamkan konsep FPB dengan strategi experiential learning yang dikemas dalam permainan yang dinamakan dengan "magic bag".

\section{Metode Penelitian}

Penelitian ini merupakan penelitian kualitatif dengan tahapan penelitian model 4D yang terdiri dari define (pendefinisian), design (perancangan), develop (pengembangan) dan disseminate (penyebaran). Pada artikel ini peneliti fokus pada hasil disseminate dengan tujuan untuk mendapatkan deskripsi tentang penerapan experiential learning pada materi KPK dan FPB di kelas IV. Subjek dalam penelitian ini adalah siswa kelas IV SDI Makarimul Akhlaq Jombang yang terdiri dari 14 siswa dan MI Asy'ari Jombang yang terdiri dari 28 siswa.

Instrumen dalam penelitian ini berupa soal-soal cerita yang berkaitan dengan materi KPK dan FPB sebanyak 3 butir soal. Soal-soal yang diberikan merupakan soal-soal penalaran dan analisa.

Pengumpulan data dalam penelitian ini menggunakan beberapa metode. Pertama, observasi yang digunakan dalam penelitian ini adalah partisipatif. Observasi dilakukan sebelum pelaksanaan penerapan pembelajaran experiential learning dengan tujuan ingin mengetahui karakteristik siswa di kelas. Selain itu, observasi juga dilakukan selama proses pembelajaran menggunakan experiential learning. Selain itu, dokumentasi juga menjadi teknik pengumpulan data. Dokumentasi dalam penelitian ini menggunakan dua kamera yaitu kamera statis dan non-statis. Dokumentasi menggunakan kamera statis bertujuan merekam segala aktivitas yang ada di kelas. Sedangkan kamera non-statis digunakan untuk merekam kegiatan siswa dalam kelompok maupun individu.
Catatan lapangan juga digunakan untuk mencatat temuan-temuan selama proses penelitian. Dalam penelitian ini, lembar soal posttest juga menjadi pengumpul data. Dalam kegiatan ini, diberikan soal sebagai evaluasi pada akhir pembelajaran. Postest dilakukan dengan tujuan ingin mengetahui apakah tujuan pembelajaran yang sudah disusun telah tercapai. Dalam postest ini siswa diberikan 3 soal uraian yaitu soal-soal cerita yang berkaitan dengan KPK dan FPB.

Teknis analisis data dilakukan dengan mengungkap data hasil rekaman video yang diperoleh selama penelitian selanjutnya dianalisa dan dikaitkan dengan teori yang digunakan. Analisis data dibagi menjadi 3 cara. Pertama, reduksi data (data reduction). Data yang diperoleh dalam penelitian ditulis dan diuraikan dengan tujuan untuk mendapat gambaran yang lebih jelas tentang hasil pengamatan, hasil kerja siswa dan rekaman video. Kedua, penarikan kesimpulan. Peneliti menentukan pola, hubungan persamaan dan hal-hal lain yang muncul selama pengambilan data selanjutnya dibuat kesimpulan. Namun kesimpulan awal ini masih besifat kabur dan diragukan sehingga perlu dilakukan verifikasi. Ketiga, triangulasi. Pada tahap ini peneliti menggabungkan berbagai sumber data dengan cara membandingkan data yang diperoleh dari hasil observasi, rekaman video, catatan lapangan dan hasil lembar kerja siswa. Selanjutnya, peneliti membuat deskripsi dari data yang sudah diperoleh.

\section{Hasil dan Pembahasan}

Pada tahap ini peneliti akan mendeskripsikan pembelajaran experiential learning sesuai dengan tahapannya.

1. Persiapan Pelaksanaan Pembelajaran Experiential Learning

Pada penerapan pembelajaran experiential learning peneliti melakukan persiapan dengan membuat Rencana Pelaksanaan Pembelajaran (RPP) dan Lembar Kerja Siswa (LKS). Pembelajaran dilaksanakan selama satu pertemuan $(2 \times 30 \quad$ menit $)$ Selanjutnya LKS tersebut diberikan kepada siswa untuk dikerjakan. Sebelum diaplikasikan 
di kelas RPP dan LKS di review oleh guru yang mengajar di kelas tersebut. Hasilnya menunjukkan bahwa RPP dan LKS dapat diterapkan di kelas dengan baik.

Pembelajaran experiential learning ini diterapkan dengan berbasis permainan. Oleh karena itu, pada tahap ini peneliti menentukan permainan yang berkaitan dengan kegiatan menemukan konsep KPK dan FPB. Permainan yang digunakan dalam penerapan pembelajaran experiential learning ini adalah Joyful Number Clap (JNC) untuk materi KPK dan Magic Bag untuk materi FPB.

\section{Concreate experience}

Pembelajaran experiential learning yang diterapkan mengaitkan antara materi KPK dengan permainan Joyful Number Clap (JNC). Dalam permainan ini siswa dibagi menjadi dua kelompok dimana kelompok yang satu harus bertepuk tangan saat guru menyebutkan kelipatan angka 2, sedangkan kelompok yang lain bertepuk tangan saat guru menyebutkan kelipatan angka 3. Para siswa yang terlibat dalam permainan ini sangat antusias. Mereka semua tertarik untuk mempraktekkan permainan ini. Hal ini dapat dilihat dari gambar 1 berikut.

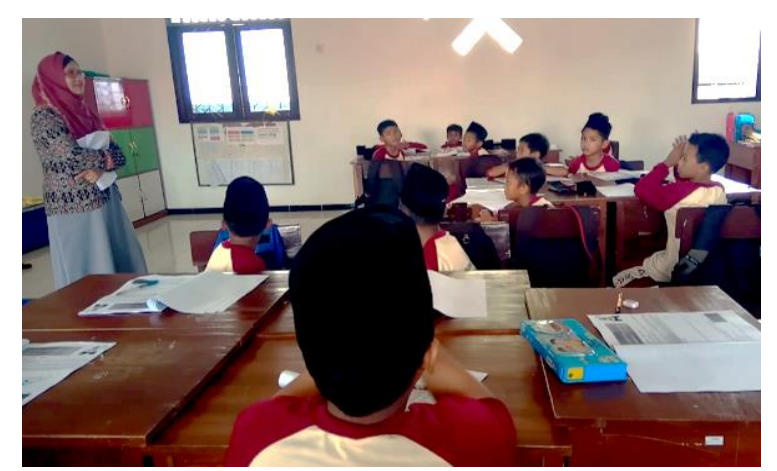

Gambar 1. Siswa melakukan permainan Joyful Number Clap (JNC)

Dari gambar 1 terlihat bahwa para siswa mulai bertepuk tangan. Mereka dapat mengikuti instruksi dari guru dengan baik. Sebagian besar siswa mengetahui kelipatan 2 dan 3. Masingmasing dari mereka dapat melakukan tepuk tangan sesuai dengan kelipatan angka yang disebutkan oleh guru. Selanjutnya, pada saat guru menyebutkan angka 6 semua siswa bertepuk tangan bersama-sama, begitu seterusnya sampai mereka memahami bahwa angka $6,12,18$ dan seterusnya merupakan kelipatan persekutuan dari angka 2 dan 3.

Dari kegiatan permainan ini, siswa mendapat pengalaman yang nyata dalam menemukan konsep KPK. Sedangkan pembelajaran experiential learning yang diterapkan mengaitkan antara materi FPB dengan permainan Magic Bag. Dalam permainan ini guru menyiapkan permen sebanyak 12 buah dan coklat sebanyak 8 buah. Guru meminta bantuan kepada salah satu siswa di kelas untuk membantunya menjawab pertanyaan. Pertanyaan yang diberikan adalah "Berapa banyak siwa yang diberi permen dan coklat agar mereka memperoleh permen masing-masing sama banyak?". Ketika pertanyaan diberikan kepada salah satu siswa, maka siswa tersebut berfikir kemudian meminta siswa lain sebanyak 4 orang maju ke depan kelas. Keempat siswa yang diminta maju ke depan kelas kemudian diberi kantong ajaib (magic bag) dimana kantong ini merupakan kantong yang digunakan untuk menyimpan hasil pembagian permen dan coklat.

Selanjutnya siswa tadi mulai membagikan permen dan coklat kepada masingmasing temannya tersebut dan memasukkannya ke dalam kantong ajaib yang dimiliki oleh keempat temannya. Hal ini dapat dilihat pada gambar 2 berikut

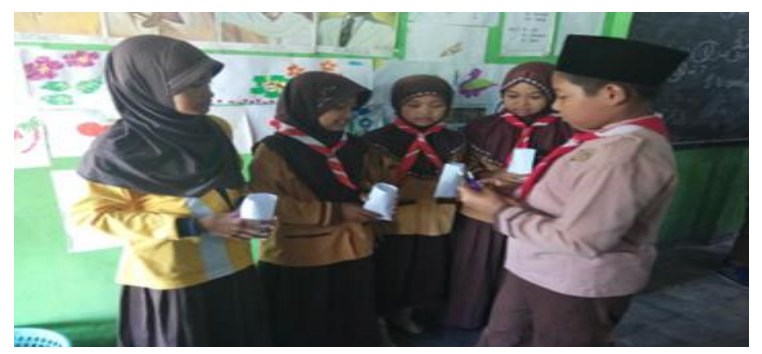

Gambar 2. Siswa membagi permen dan coklat kepada 4 orang siswa

Pada kegiatan yang terlihat di gambar 2 diatas menunjukkan bahwa masing-masing siswa mendapat permen sebanyak 3 buah dan coklat sebanyak 2 buah. Dari permainan ini, siswa mendapat pengalaman yang nyata dalam menemukan konsep FPB. 


\section{JURNAL GANTANG. September 2018; III(2): 143 - 151 \\ p-ISSN. 2503-0671 \\ e-ISSN. 2548-5547}

\section{Observation and reflections}

Pada tahap ini, siswa telah memperoleh pengalaman belajar kelipatan suatu angka dalam permainan tepuk tangan. Ketika siswa melakukan tepuk tangan secara bersama-sama, secara tidak langsung siswa telah menunjukkan bahwa kelipatan angka 2 dan 3 adalah 6, 12, 18 dan seterusnya. Pada tahap ini, dalam permainan guru mengulang angka kelipatan 2 dan 3 . Hal ini dilakukan dengan tujuan agar para siswa merenungi tentang mengapa mereka dapat melakukan tepuk tangan secara bersamaan.

Pada permainan yang melibatkan materi FPB, siswa mengalami kebingungan saat akan meminta temannya membantu di depan kelas. Siswa tersebut bingung dalam menentukan berapa banyak siswa yang dibutuhkan agar masing-masing temannya mendapat jumlah permen dan coklat sama banyak. Sehingga siswa tersebut mencoba dengan memanggil 3 teman lainnya untuk diberi permen dan coklat. Namun, ketika siswa mulai membagi coklatnya kepada masing-masing temannya, ternyata coklat tersebut tidak habis dibagi. Oleh karena itu, siswa mulai berpikir menentukan berapa jumlah teman yang dibutuhkannya. Pada tahap ini siswa tidak menyadari bahwa apa yang dilakukan merupakan penerapan dalam menentukan FPB dari 12 dan 8 . Siswa terus mencoba sampai pada akhirnya siswa mulai memahami maksud dan tujuan dari permainan ini. Siswa tersebut mulai memanggil salah satu temannya lagi untuk maju ke depan kelas. Selanjutnya dia membagi habis 12 permen dan 8 coklatnya kepada keempat temanya. Hal ini menunjukkan bahwa siwa telah berhasil menerapkan konsep FPB dalam permainan ini.

\section{Formations of abstract concept and generalizations}

Pada tahap ini, guru menjelaskan secara langsung konsep KPK dan FPB di depan kelas, sedangkan para siswa memperhatikan. Hal ini diawali dengan meminta siswa menyebutkan kelipatan 2 dan 3, selanjutnya guru menuliskan jawabannya di papan tulis. Hal ini dapat dilihat pada gambar 3 berikut.

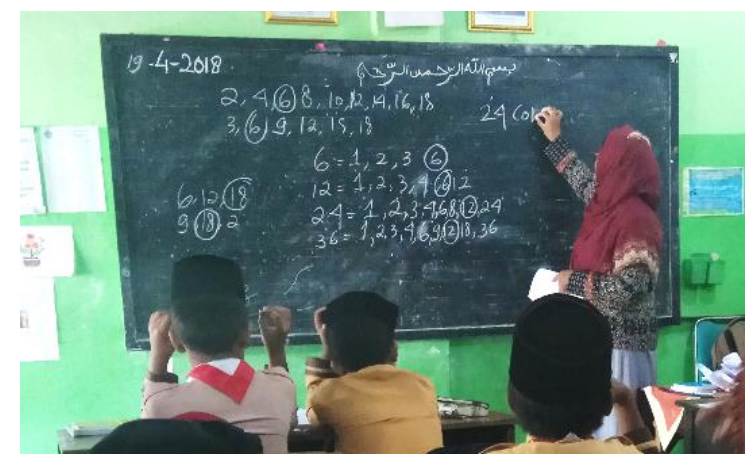

Gambar 3. Guru menulis hasil kelipatan 2 dan 3

Berdasarkan gambar 3 diatas menunjukkan bahwa hasil jawaban siswa benar. Pada kegiatan ini, guru menekankan pada angkaangka kelipatan 2 dan 3 agar siswa mampu menemukan kembali konsepnya dalam fikiran mereka.

\section{Testing implementations}

Pada tahap ini, siswa dituntut untuk bisa menggunakan pengalaman serta konsep yang sudah terbentuk dalam suatu permasalahan nyata. Pengalaman dan konsep yang diperoleh dari permainan tepuk tangan diterapkan untuk memperoleh penyelesaian dari permasalahan yang diberikan dalam LKS. Pada pelaksanaan pembelajaran experiential learning, siswa diberikan LKS untuk dikerjakan secara individu. Dalam LKS ini berisi 3 butir soal-soal cerita yang berkaitan dengan KPK dan FPB.

Soal pertama memuat permasalahan tentang KPK. Soal tersebut berbunyi: "Lonceng A berbunyi setiap 8 menit, lonceng $\mathrm{B}$ berbunyi setiap 10 menit. Bila lonceng berbunyi bersamasama pada pukul 13.15, pukul berapa kedua lonceng tersebut berbunyi bersama-sama lagi?"

Pada permasalahan ini, sebagian besar siswa dapat menyelesaikan permasalahan dengan benar dan tepat. Mereka dapat memahami bahwa soal yang diberikan merupakan permasalahan yang berkaitan dengan konsep KPK. Hal ini menunjukkan bahwa mereka dapat memahami soal dengan baik.

Dari permasalahan pertama ini, sebagaian besar siswa mampu menjawab dengan 
tepat. Meskipun, ada beberapa siswa yang masih bingung dengan langkah awal penyelesaian. Hal ini dapat dilihat pada dialog berikut.

\begin{tabular}{|c|c|}
\hline Guru & FPB apa KPK itu? \\
\hline Siswa & : KPK \\
\hline Guru & $\begin{array}{l}\text { : KPK...terus? KPK nya ketemu } \\
\text { berapa? }\end{array}$ \\
\hline Siswa & empat puluh \\
\hline Guru & $\begin{array}{l}\text { : kalau lonceng tadi itu berbunyi } \\
\text { bersama-sama pukul berapa awalnya? }\end{array}$ \\
\hline Siswa & : tiga belas lima belas (13.15) \\
\hline Guru & $\begin{array}{l}\text { : berarti pukul berapa lagi dia akan } \\
\text { berbunyi bersama lagi? }\end{array}$ \\
\hline Siswa & : empat puluh \\
\hline Guru & : pukul empat puluh? \\
\hline Siswa & : ditambah \\
\hline Guru & : ditambah berapa? \\
\hline (Siswa & erfikir) \\
\hline Guru & : empat puluh ini...empat puluh apa? \\
\hline Siswa & empat puluh KPK \\
\hline Guru & : satuannya apa? empat puluh apa? \\
\hline (Siswa & erfikir) \\
\hline Guru & $\begin{array}{l}\text { : ini tadi kan delapan.....delapan menit, } \\
\text { ini sepuluh menit, berarti ini apa } \\
\text { satuannya? }\end{array}$ \\
\hline Siswa & : empat puluh menit \\
\hline Guru & $\begin{array}{l}\text { : iya benar.....berarti ini berbunyi } \\
\text { bersama lagi pukul berapa? }\end{array}$ \\
\hline
\end{tabular}

(siswa berdikusi)

Guru : kalau yang pertama pukul 13.15 , terus setelah berapa menit lagi dia bunyi?

(siswa berdiskusi)

Guru : dia bunyi lagi empat puluh menit lagi kan?

Siswa : ya

Guru : nah empat puluh menit lagi setelah pukul ini berapa?

(siswa berdiskusi)

Guru : berapa?

Siswa : tiga belas lima lima (13.55)

Dialog di atas menunjukkan bahwa siswa sudah mampu mengenali bentuk permasalahan yang berkaitan dengan KPK. Selain itu, siswa mampu menentukan KPK dari angka 8 dan 10. Namun, berdasarkan dialog tersebut diatas terlihat bahwa siswa belum memahami bahwa kelipatan angka 8 dan 10 menunjukkan waktu yang memiliki satuan menit. Hal ini menyebabkan siswa menjadi bingung untuk menentukan langkah selanjutnya dalam penyelesaian masalah tersebut. Dalam hal ini, guru mencoba memberikan scaffolding agar siswa mampu menemukan jawabannya sendiri. Penyelesaian dari permasalahan pertama ini dapat dilihat dari hasil jawaban salah satu siswa berikut.

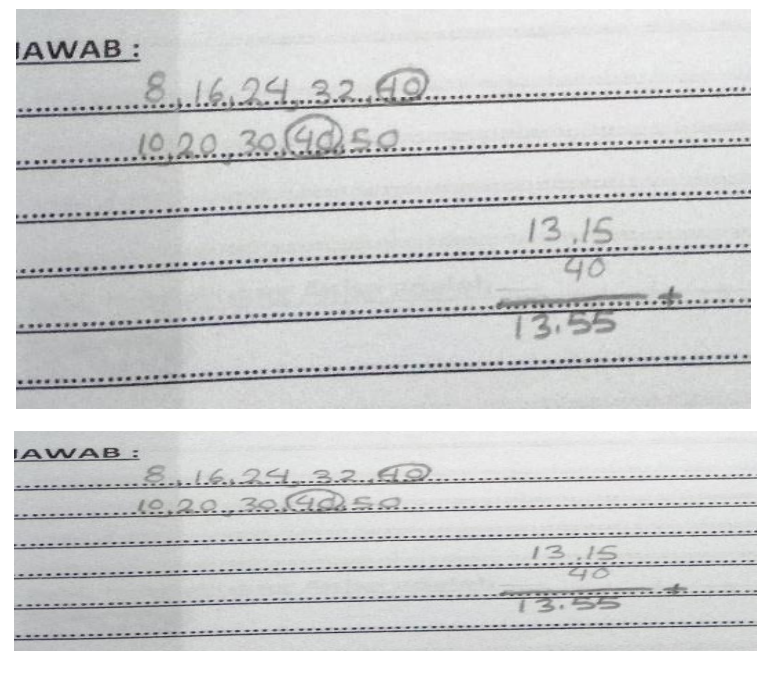

Gambar 4. Hasil jawaban siswa pada soal pertama

Soal kedua, yaitu permasalahan yang berkaitan dengan FPB. Adapun soal tersebut dapat dilihat pada kolom berikut: "Anisa membeli 36 tangkai bunga mawar merah dengan harga Rp. 7.000,00. Bunga mawar putih 24 tangkai dengan harga Rp. 3.000,00. Anisa merangkai bunga mawar merah dan putih dengan cara mengikatnya kemudian dijual $\mathrm{Rp}$. $1.500,00 / i k a t$. (a) Berapa ikat bunga yang dapat dirangkai?, (b) Berapa modal uang Anisa?, (c) Berapa keuntungan Anisa jika terjual semua?."

Pada permasalahan kedua ini, kebanyakan siswa masih bingung dalam mengenali soal yang diberikan. Mereka belum bisa mengenali apakah permasalahan yang diberikan itu berkaitan dengan konsep FPB atau KPK. Namun, ada salah satu kelompok yang mampu menjawab soal dengan benar. Dalam 


\section{JURNAL GANTANG. September 2018; III(2): 143 - 151 \\ p-ISSN. 2503-0671 \\ e-ISSN. 2548-5547}

kelompok ini, para siswa dapat menunjukkan bahwa soal tersebut merupakan permasalahan yang berkaitan dengan FPB. Adapun jawaban kelompok tersebut dapat dilihat pada gambar 5 berikut.

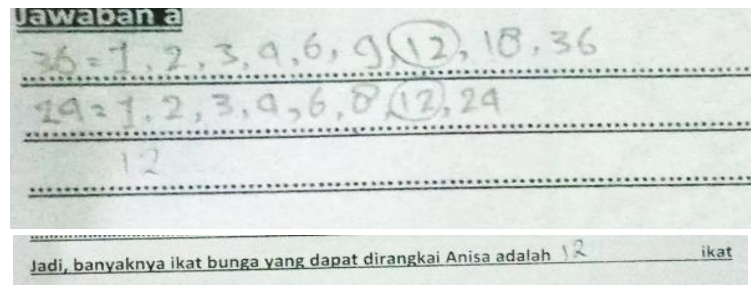

Gambar 5. Jawaban siswa pada soal 2 (a)

Berdasarkan gambar 5 diatas terlihat bahwa siswa telah mampu menentukan FPB dari 36 dan 24 dengan cara mendaftar semua faktor dari masing-masing angka tersebut. Hal ini berarti bahwa bunga yang dapat dirangkai adalah sebanyak 12 ikat. Selanjutnya, siswa harus menentukan berapa modal yang dibutuhkan Anisa pada permasalahan diatas. Hal ini dapat dilihat pada gambar 6 berikut.

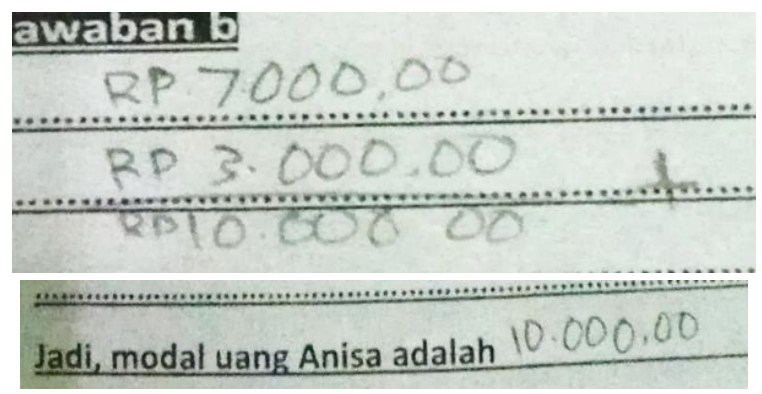

Gambar 6. Hasil jawaban siswa soal 2 (b)

Berdasarkan gambar 6 diatas terlihat bahwa siswa mampu menentukan jawaban dengan tepat. Berikutnya pada pertanyaan selanjutnya siswa juga mampu menentukan jawaban dengan tepat.

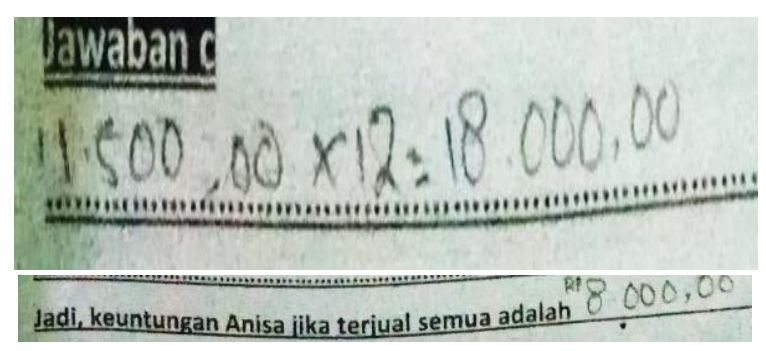

Gambar 7. Hasil jawaban siswa soal 2(c)
Pada gambar 7 dapat dilihat bahwa jawaban siswa sudah tepat. Langkah yang dilakukan adalah dengan mengkalikan banyaknya ikat bunga yang dapat dirangkai dengan harga jual tiap ikat bunga yaitu Rp. 1.500,00. Hasilnya yaitu Rp. 18.000,00 dikurangi dengan modal yang dibutuhkan yaitu Rp 10.000,00 sehingga diperoleh keuntungan sebesar Rp 8.000,00. Dalam hal ini, siswa tidak hanya belajar FPB dan KPK, namun materi aritmatika juga diperlukan dalam menyelesaikan permasalahan ini.

Selanjutnya, pada permasalahan ketiga yang diberikan adalah soal tentang waktu mencukur rambut. Soal ini berbunyi: "Rohman mencukur rambut setiap 21 hari. Ayahnya mencukur rambut setiap 30 hari. Pada tanggal 3 Januari Rohman dan ayahnya mencukur rambut bersama-sama. Pada tanggal berapa mereka akan mencukur rambut bersama-sama lagi?"

Soal diatas menunjukkan bahwa permasalahan yang diberikan melibatkan konsep KPK. Permasalahan ketiga ini konsepnya hampir serupa dengan permasalahan pertama. Adapun jawaban dari salah satu kelompok dapat dilihat pada gambar berikut.

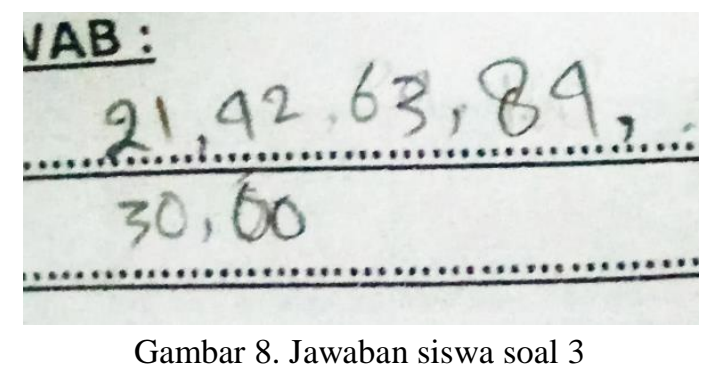

Pada gambar 8 , jawaban siswa dalam kelompok ini belum mampu menyelesaikan permasalahan yang diberikan dengan tepat. Siswa hanya berusaha menjawab soal dengan mencari KPK dari 21 dan 30. Namun dari hal ini menunjukkan bahwa siswa sudah mampu memahami bawa permsalahan yang diberikan melibatkan konsep KPK.

Pada tahap disseminate (penyebaran) ini diperoleh hasil jawaban siswa dari dua sekolah. Hasilnya menunjukkan bahwa metode yang 
diterapkan mampu membantu siswa dalam menemukan konsep KPK dan FPB. Pengalaman selama proses pemelajaran yang dikemas dalam permaianan Joyful Number Clap (JNC) dan Magic Bag membuat siswa lebih aktif dan antusias selama proses pembelajaran.

\section{Kesimpulan}

Dari penelitian ini dapat disimpulan bahwa pembelajaran eksperiensial dapat diterapkan dalam materi KPK melalui experiential learning yang dikemas dalam permainan yang diberi nama Joyfull Clap Number. Pembelajaran eksperiensial juga dapat diterapkan dalam materi FPB melalui experiential learning yang dikemas dalam permainan yang diberi nama Magic Bag. Siswa dapat memperoleh pengalaman belajar yang nyata dan bermakna sambil bermain sehingga dapat membantunya untuk membangun konsep KPK dan FPB dengan cara yang menyenangkan.

\section{Referensi}

Harfitt, G. J., \& Chow, J. L. (2018). Transforming traditional models of initial teacher education through a mandatory experiential learning programme. Teaching and Teacher Education, 73, 120-129. https://doi.org/10.1016/j.tate.2018.03.021

Henriksen, D., \& Mehta, R. (2016). A beautiful mindset: creative teaching practices in mathematics, 9(2), 81-89.

Istighafroh, Z. (2014). Pelaksanaan model pembelajaran. Pelaksanaan Model Pemebelajaran Experiential Learning Di Pendidikan Dasar Sekolah Anak Prima Yogyakarta, 1-15.

Kolb, A. Y., \& Kolb, D. a. Experiential Learning Theory: A Dynamic, Holistic Approach to Management Learning, Education and Development, Handbook of Management Learning, Education and Development 159

(2008).

https://doi.org/http://dx.doi.org/10.4135/97 80857021038.n3

Manolis, C., Burns, D. J., Assudani, R., \& Chinta, R. (2013). Assessing experiential learning styles: A methodological reconstruction and validation of the Kolb Learning Style Inventory. Learning and Individual Differences, 23(1), 44-52. https://doi.org/10.1016/j.lindif.2012.10.009

Prahmana, R. C. I. (2010). Konsep KPK siswa kelas IV A Di SD N 21 Palembang. Jurnal Pendidikan Matematika, $v, 1$.

Schwartz, M. (2013). Best practices in experiential learning. The Learning and Teaching Office (LTO) Best Practices, (36), 1-20. Retrieved from http://www.ryerson.ca/content/dam/lt/resou rces/handouts/ExperientialLearningReport. pdf

Sharlanova, V. (2004). Experiential learning. Trakia Journal of Sciences, 2(4), 36-39. https://doi.org/10.1016/B978-0-7506-72238.50017-4

Silberman, M. (2014). Handbook experimental learning strategi pembelajaran dari dunia nyata (I). Bandung: Nusa Media. 
JURNAL GANTANG. September 2018; III(2): 143 - 151

p-ISSN. 2503-0671

e-ISSN. 2548-5547 